\title{
Teaching NeuroImages: Distinctive imaging in a paucisymptomatic child with leukodystrophy
}

Indar Kumar Sharawat, MD, Lokesh Saini, DM, Ananthanarayanan Kasinathan, DM, Amrit Kaur, MBBS, and Naveen Sankhyan, DM

Neurology ${ }^{\circledR}$ 2018;91:e1368-e1369. doi:10.1212/WNL.0000000000006280
Correspondence

Dr. Saini

drlokeshsaini@gmail.com

Figure MRI brain

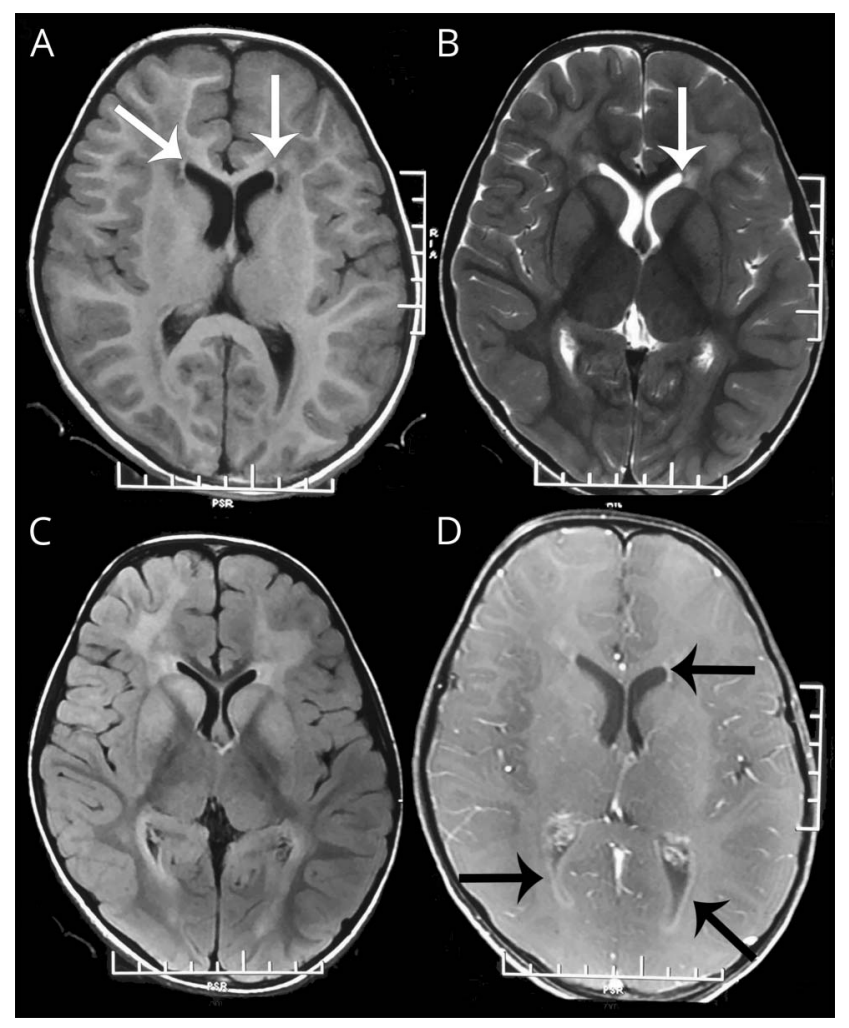

(A) Axial T1-weighted image shows thin periventricular hyperintense rim (arrows), which was hypointense on (B) T2-weighted image (arrow). (B) Confluent T2weighted and (C) fluid-attenuated inversion recovery hyperintensities in bilateral periventricular deep and subcortical cerebral white matter (frontal dominant), striatum, and thalami. (D) Postgadolinium axial section shows a thin rim of ependymal enhancement predominantly in trigone and minimally in the frontal horn of lateral ventricles (arrows).

An 8-year-boy, born to nonconsanguineous parents, presented with a history of 2 unprovoked generalized seizures in the preceding 5 years. The examination was unremarkable. An awake EEG showed occasional bifrontal sharps. Based on the MRI brain (figure, A-D) and the detection of a pathogenic variant ${ }^{1}$ (c.262C $>\mathrm{T}[\mathrm{p}$. Arg88Cys], exon 1) on GFAP gene sequencing, a diagnosis of Alexander disease was confirmed. The child remained asymptomatic during a 3-year follow-up period.

\section{MORE ONLINE}

$\rightarrow$ Teaching slides

links.lww.com/WNL/ A686

Alexander disease is an astrogliopathy, characterized by megalencephaly, pyramidal signs, progressive psychomotor retardation, ataxia, pseudobulbar signs, and seizures. ${ }^{2}$ However, a rare 
patient may be paucisymptomatic for several years. ${ }^{2}$ The imaging findings are distinctive and allow for directed genetic testing and confirmation.

\section{Author contributions}

I.K.S.: patient management, literature review, initial draft manuscript preparation. L.S.: concept and design of the study, analysis of the radiologic data, critical review of manuscript, final approval of the version to be published. A. Kasinathan: patient management, literature review, initial draft manuscript preparation. A. Kaur: patient management, literature review, initial draft manuscript preparation. N.S.: clinician-in-charge, concept and design of the study, critical review of manuscript for important intellectual content, final approval of the version to be published.

\section{Study funding}

No targeted funding reported.

\section{Disclosure}

The authors report no disclosures relevant to the manuscript. Go to Neurology.org/N for full disclosures.

\section{References}

1. van der Knaap MS, Ramesh V, Schiffmann R, et al. Alexander disease: ventricular garlands and abnormalities of the medulla and spinal cord. Neurology 2006;66:494-498.

2. Gorospe JR, Naidu S, Johnson AB, et al. Molecular findings in symptomatic and presymptomatic Alexander disease patients. Neurology 2002;58:1494-1500. 


\section{Neurology}

\section{Teaching NeuroImages: Distinctive imaging in a paucisymptomatic child with leukodystrophy}

Indar Kumar Sharawat, Lokesh Saini, Ananthanarayanan Kasinathan, et al. Neurology 2018;91;e1368-e1369

DOI 10.1212/WNL.0000000000006280

\section{This information is current as of October 1, 2018}

\section{Updated Information \&} Services

References

Subspecialty Collections

Permissions \& Licensing

\section{Reprints}

including high resolution figures, can be found at: http://n.neurology.org/content/91/14/e1368.full

This article cites 2 articles, 2 of which you can access for free at: http://n.neurology.org/content/91/14/e1368.full\#ref-list-1

This article, along with others on similar topics, appears in the following collection(s):

Developmental disorders

http://n.neurology.org/cgi/collection/developmental_disorders MRI

http://n.neurology.org/cgi/collection/mri

Information about reproducing this article in parts (figures,tables) or in its entirety can be found online at:

http://www.neurology.org/about/about_the_journal\#permissions

Information about ordering reprints can be found online:

http://n.neurology.org/subscribers/advertise

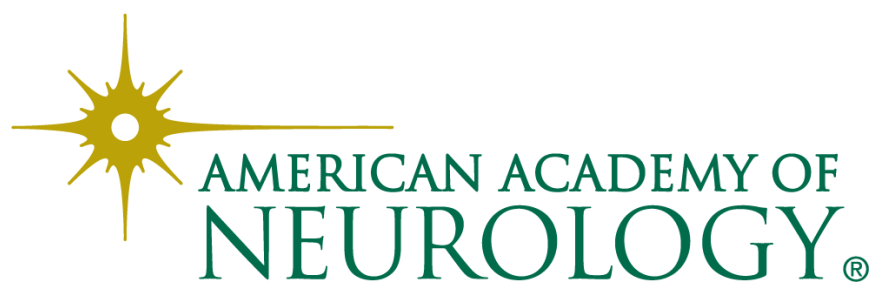

